\title{
Görögország államadósság-válsága kezelésének jövőbeli jogi és közgazdasági akadályai - a privatizáció mennyiben lehet megoldás? TÖRÖK LÁSZLÓ
}

Egy állam szuverén bruttó államadósságának megengedhető mértékére nincs szabály sem a jogban, sem pedig a közgazdaságtanban. Talán, ha lett volna ilyen, Görögország nem került volna arra a kritikus finanszírozási plafonra, ahol több mint egy évtizede van. A cikk röviden bemutatja, hogyan jutott ide Görögország, milyen a hitelezőkkel egyeztetett és általuk támogatott lépéseket tett államadóssága finanszírozhatóságának fenntarthatósága érdekében, s azok milyen eredményre vezettek. Elözőnél részletesebben taglalja a szerzö azt, hogy milyen kényszerü intézményi változások kezdödtek el a közelmúlt éveiben és vannak folyamatban napjainkban (köztük a privatizáció dinamizálása) azért, hogy a görög állam fizetöképessége fennmaradjon úgy, hogy közben államadóssága csökken. Erre a szerzö által felvázolt társadalmi-gazdasági környezetben minimális esély mutatkozik, csökkenés elérhetö, mértéke azonban nem tünik elégségesnek. Zárógondolatként fogalmazódik meg az, hogy társadalmi konszenzus hiányában a görög intézményi reformok véghezvitele igencsak kétséges, valamint hogy - görög példa alapján - a jogalkotóknak talán el kellene gondolkodniuk egy önálló állami csödjog megalkotásán annak érdekében, hogy a befektetök/hitelezök által a szuverén államokkal megkötött hitelszerzödések jogi kikényszerithetösége biztositott legyen.

Journal of Economic Literature (JEL) kód: G01, H63.

https://doi.org/10.47630/KULG.2018.62.1-2.4

Török László, PhD, ügyvezető, Hajdúsági-FLOTT Kft., óraadó, Debreceni Egyetem. E-mail: torok159@freemail.hu 


\section{A szuverén államadósság teoretikus értékeiről}

A makroökonómiában nincs egzakt szabály arra vonatkozóan, hogy mi az optimális mérték egy adott nemzetgazdaság adósságrátájára. Az IMF szerint 50 százalék feletti arány már veszélyes mértékűnek számít, ezt azonban empirikus kutatással nem támasztották alá. A maastrichti szerződésben foglalt 60 százalékos numerikus arány egy konvencionális megállapodás terméke, egyfajta igazodási pont. Több példát lehet arra felhozni, hogy jóval az előbb említett mérték feletti adósságrátával rendelkező ország kiegyensúlyozott gazdasági növekedést realizál, és államadósságának piaci finanszírozása gond nélküli, ezáltal gazdaságpolitikáját más prioritások vezérlik, mint például Németország, ahol a GDP-arányos bruttó államadósság 68,1 százalékos. Ennek ellenkezőjére is hozható példa, ilyen Spanyolország esete, amelynek 2010. évi GDP-arányos államadóssága pontosan 60 százalék volt, de finanszírozási gondjai már ekkor elkezdődtek, azóta pedig tovább súlyosbodtak. A 60 százalékos mérték tehát semmiképpen nem az optimum. A 90 százalékot meghaladó értékek ellenben aggasztóak, ugyanis egy modellszámításon nyugvó alapos elemzés szerint, ha egy fejlett ország államadóssága meghaladja ezt a mértéket, akkor gazdasági növekedése lelassul, ami mérsékli az adósságszolgálathoz nélkülözhetetlen adóbevételeket, ezáltal növelve az államcsőd veszélyét. Reinhart-Rogoff [2010] megállapítása szerint az ilyen államadósság körüli értékkel rendelkező nemzetgazdaságok átlagosan 3 százalékkal alacsonyabb gazdasági növekedést produkáltak, mint azok az országok, ahol az adósságráta nem volt magasabb a 30 százaléknál. A felzárkózó országok esetében a további adósságnövekedésnek ez az önpusztító mechanizmusa már 60 százalékos GDP-arányos államadósságnál beindulhat. Ennek a 90 százalékos teoretikus értéknek ${ }^{1}$ éppen dupláját (180,8 százalékot) realizálta Görögország 2016 végére. Ez az állapot még jó ideig fenntartja a görögországi államcsőd veszélyét, holott az ennek elkerülésére megfogalmazott euróövezeti fenyegetettség kimondja, hogy bekövetkezésekor no exit (nincs kilépés), no default (nincs átütemezés) és no bail out (nincs központi banki kiigazítás). (Nizzai Szerződés, 2001)

${ }^{1}$ Az államadóssággal foglalkozó szakpolitikában folyamatos diskurzus zajlik annak fenntartható mértékéröl. Konkrét GDP-hez mért arányt nehéz lenne meghatározni, ezzel szemben Guzman [2016] megfogalmazza a fenntarthatatlanság alternatív definícióját, amely szerint az államadósság nem fenntartható, ha az adós politikailag nem kivitelezhetó és nem következetes makrogazdasági politikát folytat az államadósság kezelésére. Több kritika is érte az amerikai szerzőpáros 90 százalékos teoretikus mértékét, lásd erröl részletesebben: The Economist [2013]. 


\section{Görögország államadósságának kialakulásáról és annak következményeiről}

Görögország az Európai Unió gazdaságilag - és mindinkább politikailag leggyengébb láncszeme. Ez leginkább államadósságának mértéke és főleg annak kezelhetetlensége okán fenyegeti az unió jövőjét, veszélyezteti a Gazdasági és Monetáris Unió egészét. Az ország Európai Unióba történő 2001. évi belépése ${ }^{2}$ óta küszködik strukturális problémákkal. Ebből következően másfél évtizede az ország és fö hitelezői az Európai Bizottság, az Európai Központi Bank és a Nemzetközi Valutaalap, valamint az egyéb nemzetközi hitelezők folyamatosan erőfeszítéseket tesznek az ország államadósságának mérséklésére hiteleik kedvezőbb kondíciójú cseréjével, esetenként (miként azt később látni fogjuk) részleges leírásával.

\section{Görögország és az Európai Unió költségvetési hiányának alakulása} (2005-2016, százalékban)

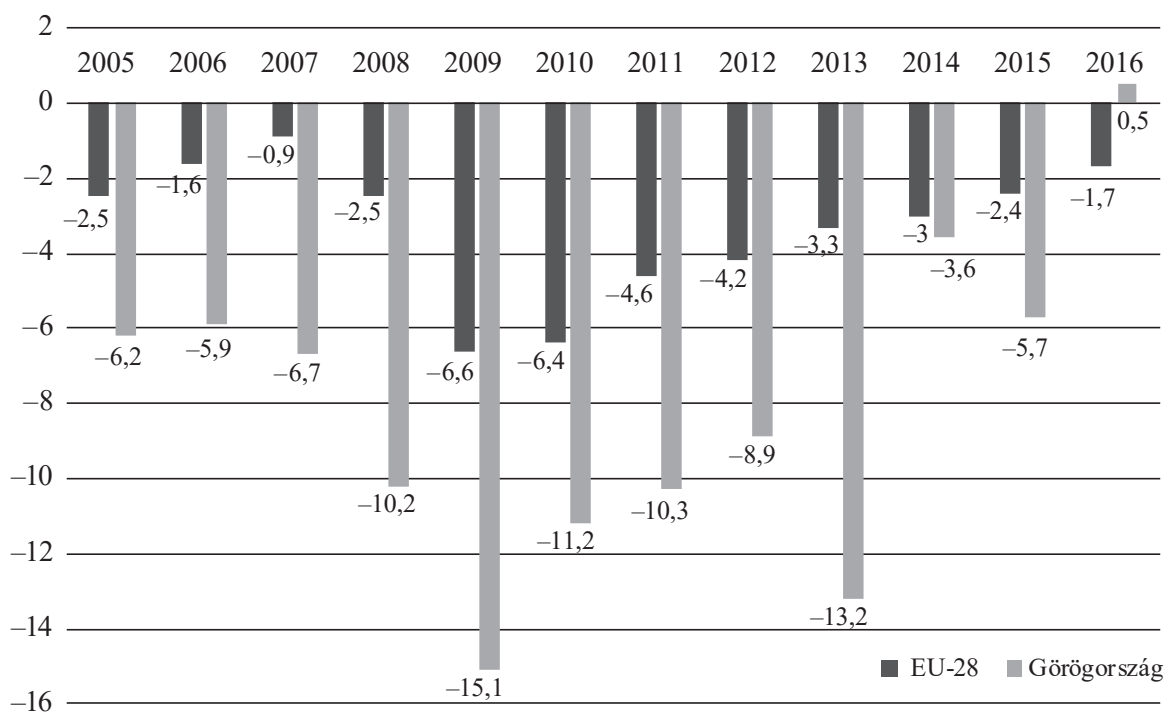

Forrás: Eurostat [2017a] alapján saját szerkesztés.

${ }^{2}$ Az Európai Unióba történő belépéshez szükséges konszolidációt Görögország 1999-re elsősorban a pénzügyminiszter szerepének erősítésével és az adóadminisztráció szigorításával érte el, bár mint utólag kiderült, a konszolidáció „megvalósulásában” költségvetési adatok kozmetikázása is szerepet játszott (Hallerberg, 2004). 
A következőkben röviden bemutatom, hogy milyen gazdasági folyamatok vezettek ahhoz, hogy az ország közel egy évtizede szinte folyamatosan a szuverén államadósság visszafizethetetlenségének veszélye miatt államcsőd közeli állapotban van.

Az 1. ábráról jól látható, hogy a görög állam költségvetési hiányának (general government deficit) aránya a vizsgált 2005-2016 közötti intervallumban (2016 kivételével) jelentősen meghaladta az uniós átlagot. Ez önmagában nem feltétlenül jelezne kezelhetetlen államadósság-problémát. Az azonban már igen, hogy az idősorelemzés elvégzésével az válik láthatóvá, hogy míg az unió átlagos költségvetési hiányának növekedési átlaga 3,31 százalék/év, addig Görögországé 8,04 százalék/év, tehát közel háromszorosa annak. Arról, hogy milyen gazdasági és társadalmi folyamatok vezettek ahhoz, hogy 2016 végén a görög szuverén államadósság elérje az ország GDP-jének 180,8 százalékát, több elemzés is készült. Itt és most csak röviden Győrffy [2014, 33. o.] tanulmányában leírt összegzést idézem, mely szerint összességében a válság előtti Görögország jellemzője, hogy az állam legitimitását nem a hatékony kormányzásra, hanem a munkahelyek biztosítására, populista osztogatásra és a fogyasztás növelésére alapozta. Ez nagyon kedvezötlen üzleti környezetet teremtett a magánszektor számára, amit valamennyire ellensúlyozott az adók beszedésének lazasága.

2. ábra

\section{Görögország és az Európai Unió GDP-hez mért bruttó államadósságának alakulása}

(2005-2016, százalékban)

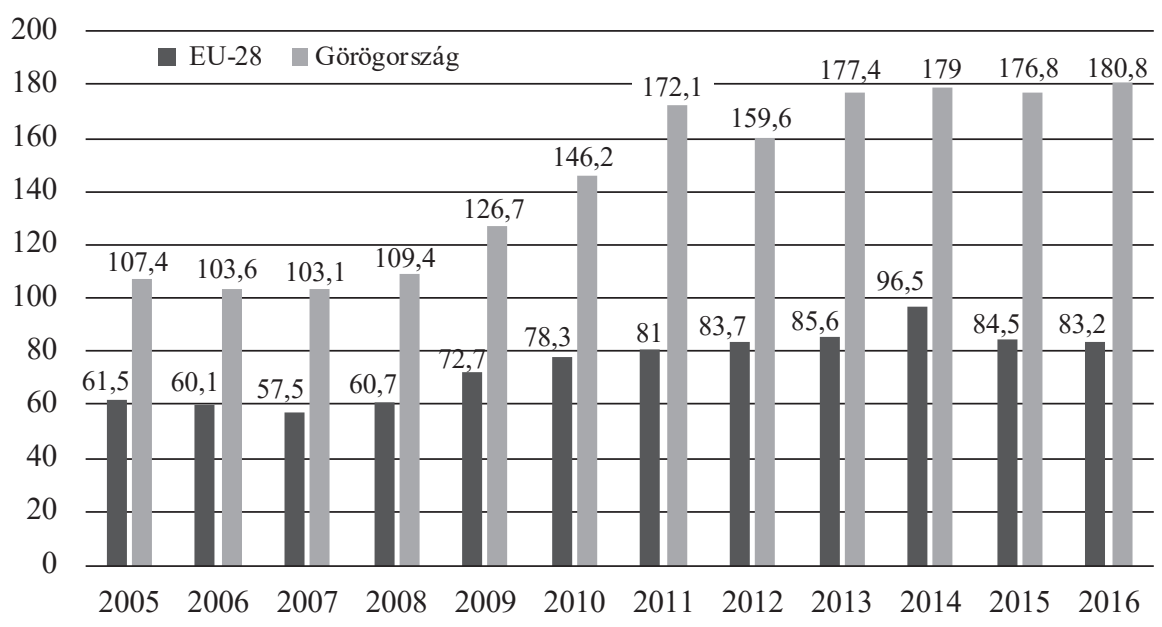

Forrás: Eurostat [2017b] alapján saját szerkesztés. 
A 2. ábráról is jól látható és az idősor adatainak statisztikai átlagából számított 145,2 százalékos érték közel kétszerese az unió 74,6 százalékos átlagos értékének, ami azt jelenti, hogy Görögország GDP-hez mért átlagos bruttó államadósságának (average general government gross debt) értéke csaknem duplája az Európai Unió hasonló mutatójának. Ennél az értéknél is kritikusabb az, hogy míg az unió bruttó államadósság-növekedési dinamikája a vizsgált időszakban 1,81 százalék/év, addig Görögországé 6,12 százalék, tehát a növekedés sebessége több mint háromszorosa annak, ami előrevetíti a finanszírozás hosszú távú fenntarthatatlanságát. A jelenlegi kritikus finanszírozási helyzetet azonban már megelőzte egy hasonló krízis. A 2009ben mutatkozó, a GDP-hez mért 126,7 százalékos bruttó államadósság (lásd a 2. ábrát) és az Európai Unióban addig példa nélküli 15,1 százalékos költségvetési hiány (lásd az 1. ábrát) elkerülhetetlenné tette a finanszírozási válság kezelését, amely részleteinek bemutatásától itt most eltekintek, ${ }^{3}$ csak a pénzügyi mentőcsomagok főbb elemeit ismertetem Győrffy [2014, 35. o] alapján. Azokat mutatom be, amelyek magyarázatot adnak a görög bruttó államadósság 2012. évi 51,2 milliárd euró összegü csökkenésére (lásd a 3. ábrát). Az EU és az IMF 2010 májusában döntött úgy, hogy 110 milliárd eurós mentőcsomagot nyújt Görögországnak hároméves időtartamra. A csomagból 80 milliárd eurót fizettek az euróövezet tagállamai, 30 milliárdot pedig az IMF biztosított készenléti hitelmegállapodás keretében. A csomag feltételeként költségvetési konszolidációt (2014-re a hiány 3 százalék alá csökkentését), illetve szerkezeti reformokat írtak elő. A válság miatt azonban Görögország 2011-ben nem tudott visszatérni a nemzetközi tőkepiacokra. Pénzpiaci hozzáférés hiányában újabb mentőcsomag vált szükségessé, amelyet 2012 márciusában véglegesítettek. Ennek feltételei azt célozták, hogy 2014-re 4,5 százalékos elsődleges többlettel zárjon a görög költségvetés, illetve 2020-ra 120 százalékra csökkenjen az adósságállomány. Az EU 2012 novemberében további megszorítások fejében hajlandónak mutatkozott a feltételek könnyítésére, és eltolta a hiány 3 százalék alá történő teljesítését 2016-ig. A hitelkamatok csökkentése, illetve a lejárat meghosszabbítása szintén könnyítésnek tekinthető, amely felért egy új 40 milliárd eurós csomaggal. Az EKB 42 milliárd euró értékben vett görög állampapírt, amelyek névértéke 60 milliárd euró volt, a vételi ár és a névérték közötti különbséget elengedték Görögországnak. Végül az európai hitelezők 2015-ben állapodtak meg Görögországgal a harmadik, 86 milliárd eurós összegü mentőcsomag részleteiben. Amint az a 3. ábra adataiból kitünik, a

3 A mentőcsomagok feltételeiről lásd: Európai Bizottság [2010], az általuk elért hatásokról, eredményekröl részletesebben lásd: Györffy [2014]. 
görög bruttó államadósság érdemben nem volt képes csökkenni, összege 2016-ban meghaladta a 315 milliárd eurót, aránya az éves GDP-hez a 180,8 százalékot.

3. ábra

Görögország bruttó államadósságának alakulása

(Millió euróban, 2005-2016)

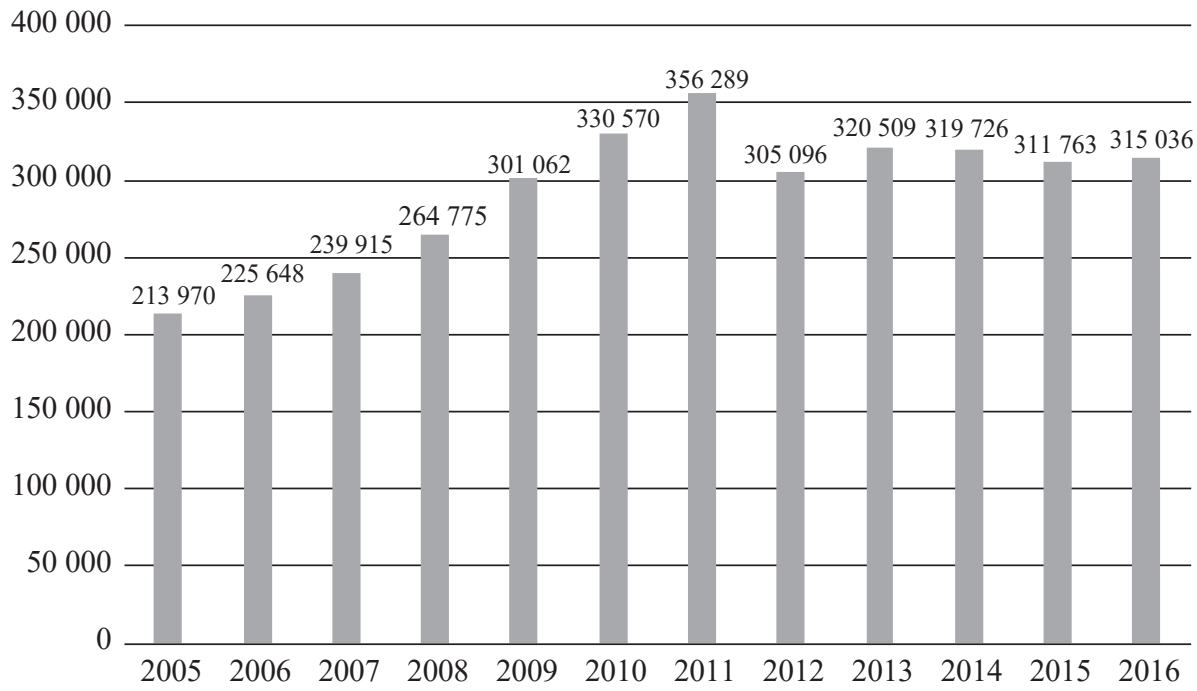

Forrás: KSH [2017] alapján saját szerkesztés.

Görögország szuverén államadósságának elméletileg lehetséges kimenetei

A görög államadósság problematikája Damoklész kardjaként lebeg az Európai Unió (és az euróövezet) felett. Joggal merül fel a kérdés: hogyan lehetne ettől az egyre nyomasztóbb és szinte megoldhatatlannak tűnő finanszírozási problémától megszabadulni? A következőkben sorra veszem a permanensen fennálló pénzügyi válságkezelés elméletileg lehetséges megoldásait, megvilágítva azok jogi és közgazdasági aspektusait. 
Baksay-Palotai [2017] szerint a felelőtlen költségvetési politikát sem a laza, az adósság ütemesebb elinflálását megengedő monetáris politika, sem a túlzottan szigorú, a növekedést az árstabilitásért feláldozó monetáris politika nem tudja megfelelően korrigálni. Közgazdaságilag kézenfekvő megoldásnak tünik a görög államadósság elinflálása. ${ }^{5}$ Ennek során az adósságot birtokló hitelezők, a kötvénytulajdonosok szenvednék el a veszteséget. Pénzügy-technikailag az elinflálás során a hiteleket felvevő görög kormány és a monetáris hatóság (National Bank of Greece, NBG) mesterségesen alacsonyan tartaná a kamatszintet, illetve adott esetben kötvénypiaci intervencióval az ún. hosszú oldali hozamokat is, miközben az inflációs ráta ezeknél az alacsonyan tartott hitel-/kötvénykamatoknál magasabb lenne. Ennek következményeként kialakulna egy negatív reálkamatszint, amelynek segítségével az államadósság csökkenő ütemü pályára állna. Az adósság reálértéke tehát - a vázolt mechanizmusban - folyamatosan képes lenne csökkeni. Az ún. „meglepetés inflációval" valóban csökkenthető az államadósság, egy adott nemzetgazdaságban azonban ennek jelentős költsége van mind rövid, mind pedig hosszú távon. Az infláció csökkentheti az államadósságot, de ezzel párhuzamosan más gazdasági szereplök vagyonát is értékteleníti. A meglepetés infláció hosszabb távon is komoly költségekkel jár, aláássa ugyanis a gazdasági szereplőknek a gazdaságpolitika alacsony infláció melletti elkötelezettségébe vetett bizalmát, pénzügy-technikailag azonban alkalmas az államadósságok értékvesztésére.

Az előzőekben részletezett megoldás azonban Görögország esetében nem jöhet számításba, annak ugyanis jogi akadályai vannak, mivel a görög jegybanknak tilos meghiteleznie az állami költségvetés hiányát (amelyek kumulált összege az államadósság). A maastrichti konvergenciakritériumok alapján az államháztartási defi-

${ }^{4}$ A szuverén bruttó államadósságok vissza nem fizetéséről és azok elinflálásáról részletesebben lásd: Krugman [2012].

${ }^{5}$ Kiváló történelmi példa erre, amikor a II. világháború után hatalmasra duzzadt amerikai államadósság leépítésének céljából a Fed (az USA központi bankja) 2,5 százalékon fixálta a hosszú oldali állampapírhozamokat, miközben az inflációs ráta ennél jóval magasabb szintet ért el. Volt olyan év, amikor a megtakarítók két számjegyủ negatív reálkamatot szenvedtek el. Az amerikai államkötvények átlagos hátralévő futamideje 9,4 év volt 1947-ben, kamatuk 2,9 százalék, miközben az infláció például 1942 és 1952 között 68,8 százalék volt. Vagyis a kötvénytulajdonosok az infláció miatt elvesztették vagyonuk felét 10 év alatt, de a hosszú futamidő mellett nem tudtak ez ellen semmit tenni. (Az ő veszteségük az adósság szempontjából az állam nyeresége volt.) Kérdés természetesen, hogy erre a megtakarítók hogyan reagálhatnak. Elméletileg lehetőségük van arra, hogy más devizában, más régióban magasabb hozamú eszközökbe fektessenek, ennek azonban lehetnek korlátai. Egyrészt a magasabb hozam magasabb nemfizetési kockázattal is járhat, így ezek az eszközök kevésbé vonzók (Concorde, 2018). 
citeket nem lehet saját jegybanki hitelekkel finanszírozni, holott az államadósság elinflálásának ez az egyik technikai feltétele lenne. A csatlakozás egyik intézményi korlátja ugyanis a jegybankok teljes függetlensége; ez a költségvetési hiány közvetlen jegybanki finanszírozásának tilalmát is jelenti. E feltétel hivatott gondoskodni arról is, hogy az államadósság terhének elinflálása a leendő tagországokban még ötletként se merülhessen fel. S ami a legfontosabb: a közös jegybank (az Európai Központi Bank, $E C B)$ a tagországok kormányaitól való teljes intézményi függetlenséget élvez, és a statútumában megjelölt alapvető feladata abban áll, hogy a pénzügyi unió tagországainak árstabilitása felett őrködjék, ami így mindenképpen ellenállna az elinflálásnak (Oblath, 1999). A Tradingeconomics [2018] tanulmányában látható, hogy Görögország államadósságot finanszírozó hosszú lejáratú (long term) kötvényei kamatának trendje - a jelentős hullámzás ellenére ${ }^{6}$-átlagosan tíz százalék körül alakult. A 2006-2016 közötti időszakban az infláció -1,1 és 4,7 százalékos volt a Eurostat [2017c] szerint, amiböl következik, hogy a vizsgált időszakban az államadósság elinflálásának veszélye és (mint azt az előzőekben bemutattam) lehetősége nem állt fenn.

Az államadósság törlesztésének egyoldalú felmondása

Az államadósság törlesztésének egyoldalú felmondása elméleti lehetőségként kétségtelenül vonzó teória lehet minden kezelhetetlennek tủnő államadósság-finanszírozási helyzetben lévő ország számára. Az államadósságot megtestesítő hitelek/ kötvények visszafizetésének egyoldalú felmondását a görögök részéröl az teszi lehetetlenné, hogy az adósság 82 százaléka külföldiek tulajdonában van, ami jelentősen megnehezíti az egyoldalú felmondást (Monokroussos et al., 2015). Ilyen esetekben ugyanis a hitelezők jogot szerezhetnek külföldön levő görög vagyonelemek lefoglalására is, és az ország hosszú időre kiszorul a nemzetközi pénzpiacokról Győrffy [2017] szerint, ami azzal a következménnyel járna, hogy még a jelenleginél is sokkal drágábban, vagy egyáltalán nem tudna forrásokat bevonni külföldről. Ez abból következne, hogy Görögország országkockázata jelentősen növekedne, ami olyan kockázati elemek összessége Görögország vonatkozásában is, amelyek azzal kapcsolatosak, hogy egy ország rezidens gazdasági szereplöje, nem szuverén adósa (je-

${ }^{6}$ Az államkötvény-kamatok jelentős emelkedésének beindulására ad magyarázatot az, hogy 2009 decemberében a görögök elismerték és bejelentették, hogy az államadósság elérte a 300 milliárd eurót, azaz a GDP 113 százalékát. A bejelentésre a hitelminősítő intézetek is gyorsan reagáltak, és az országot bóvli kategóriába sorolták (Györffy, 2017). 
len esetben kormánya) nem képes vagy nem akar egy másik ország kormányával, rezidens gazdasági szereplöjével vagy nemzetközi intézményekkel szemben fennálló fizetési kötelezettségeinek eleget tenni. Az államadósságot finanszírozó hitelek/ kötvények törlesztésének egyoldalú megtagadása az utóbbit jelentené. Más megközelítésben az országkockázat ahhoz a valószínüséghez kapcsolódik, hogy az üzleti környezetben bekövetkezett változások csökkentik az adott országban való üzleti müködés profitabilitását. Ezek a változások nem csak a befektetők nyereségét érinthetik hátrányosan, hanem a befektetett eszközök értékét is, jelentősen leértékelve azokat. A görög államadósságot finanszírozó befektetők a hazainál (elsősorban az euróövezet országairól van itt szó, lásd a 4. ábrát) nagyobb kockázatot vállalnak,

4. ábra

\section{Görögország nemzetközi hiteleinek összetétele 2015-ben}

(Milliárd euróban)

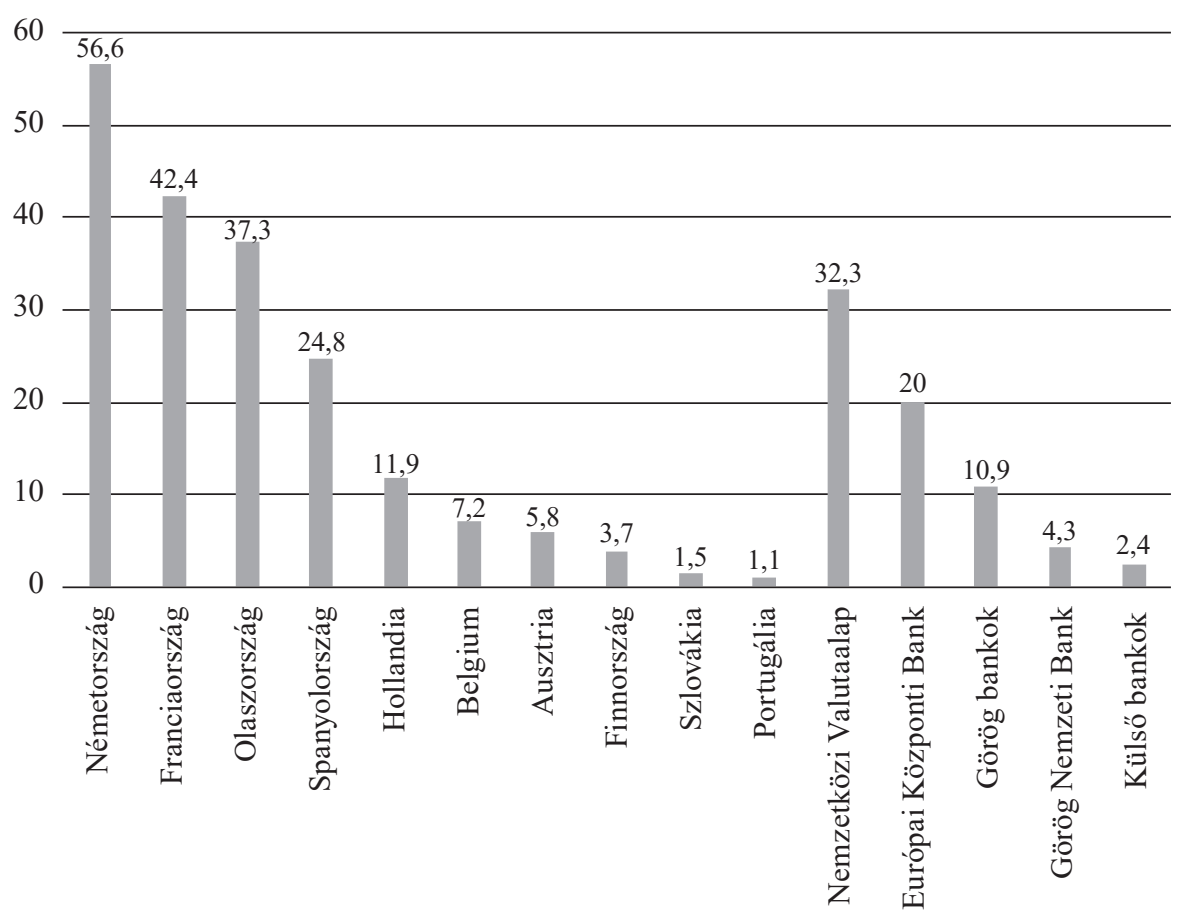

Forrás: Górniewicz [2016] alapján saját szerkesztés. 
amikor saját nemzetgazdaságuk ismert jogi és gazdasági környezetétől eltérő feltételek között helyezik el tőkéjüket görög államkötvényekbe. A hozam és a kockázat közötti összefüggés alapján minél kisebb a külföldi tőkebefektetés többletkockázata egy országban, annál nagyobb annak vonzereje, ebből következően több tőkebefektetés irányul oda. Az összefüggés megfordítva is igaz, minél alacsonyabb a többletkockázat egy országban, annál alacsonyabb lesz a tőke ára, azaz a hitelfelvevők annál alacsonyabb kamatláb mellett jutnak forráshoz. Az országkockázat tehát két tényezőből áll. Az egyik a politikai kockázat, a másik a transzferkockázat. A politikai kockázat a fizetési készségre, a transzferkockázat a fizetési képességre vonatkozik (Gray, 2013). A két kockázat jelentkezhet külön-külön és együtt is. Görögország esetében ez utóbbiról lenne szó. A döntően külföldi hitelezők (lásd a 4. ábrát) szempontjából a görög nemzetgazdasággal kapcsolatos pénzügyi kockázat tehát országkockázatként jelenne meg. A törlesztések egyoldalú felmondása esetén Görögország országkockázata olyan magasra szökne, hogy a nemzetközi pénzpiacon nem találna olyan befektetőket, akik kötvényvásárlásokkal vállalnák államadósságuk finanszírozását, formálisan bekövetkezne az állam csődje.

A görög államadósság elengedése

A görög szuverén államadósság hitelezők általi elengedésére a németek szerint jogilag nincs lehetőség, ezt Németország vezető politikusai többször kijelentették. Állásfoglalásukat valószínűleg a már hivatkozott Nizzai Szerződés ${ }^{7}$ szövegére alapozzák, amelyben szerepel a „no bail out” (nincs központi banki kiigazítás), ami tartalmában az államadósság hitelezők általi elengedésével egyenértékű. A németek álláspontja érthetőnek tünik, ugyanis (lásd a 4. ábrát) ők a görög államadósság legnagyobb hitelezői, ezért pénzügyi tekintetben erre ök a legérzékenyebbek. Az más helyzet lenne, amennyiben Görögországot ki lehetne zárni akár az Európai Gaz-

${ }^{7}$ Az Európai Unió jelenleg hatályos alapszerződése, a Nizzai Szerzödés 103. cikke szerint a Közösség nem felel a tagállamok kormányzati szerveinek, regionális, helyi vagy egyéb hatóságainak, egyéb közjogi intézményeinek és állami vállalatainak a kötelezettségeiért, és nem vállalja magára azokat. Ezzel párhuzamosan egyik tagállam sem felel egy másik tagállam kormányzati szerveinek, regionális, helyi vagy egyéb hatóságainak, egyéb közjogi intézményeinek és állami vállalatainak kötelezettségeiért és nem vállalja magára azokat. Ez az úgynevezett ki nem segítési cikk (no bail out). Ebből a cikkből az következik, hogy az államháztartás mindenkori állapotáért a nemzeti kormányok felelnek, adott esetben sem a Közösség, sem pedig a többi tagállam nem kötelezhető segítség nyújtására. Az antiinflációs gazdaságpolitika érvényesítésének elve alapján ez felveti - elméletileg legalábbis - az államcsőd lehetőségét is, azaz azt, hogy a szuverén adósok képtelenek adósságaikat megfizetni. A nemzeti kormányok ugyanis az államháztartás hiányát nem finanszírozhatják a pénzkibocsátás eröteljes növelésével (Losoncz-Farkas, 2011, 49. o.). 
dasági és Monetáris Unióból, akár az Európai Unióból. Releváns szempont, hogy jogi lehetőségek hiányában Görögországot beleegyezése nélkül nem lehet kizárni sem az EGMU-ból, sem pedig az EU-ból, a távozást csak és kizárólag egyeztetett tárgyalásokkal lehetne elérni. Jogi lehetőségek hiányában a tagállamok nem tudják rákényszeríteni Görögországot a távozásra, a piacok azonban kikényszeríthetnek olyan helyzetet, amelyben a görög kormány maga kezdeményezi a távozást. Az EG$M U$-ból való kilépés és az azt követő helyzet sincs jogilag szabályozva. Az EGMU önkéntes elhagyása, illetve Görögország kizárása tehát csak új jogi keretek között lenne lehetséges. Ehhez vagy ki kell egészíteni az Európai Unióról és az Európai Unió müködéséről szóló szerződést, vagy hozzá kellene kapcsolni egy olyan tartalmú jegyzőkönyvet, amely azt lehetővé teszi. Mindkét esetben a tagállamok hozzájárulására lenne szükség, a kizárás és/vagy a kilépés jelentősége miatt a ratifikáció hosszabb időt venne igénybe. Egyszerübb és más szempontból is praktikusabb (bár hosszadalmasabb) lehet Görögország esetleges távozása az Európai Unióból a TEU 50. cikke alapján (Gálik, 2012). Jogelméletileg elképzelhető lenne még az Európa Tanács Görögország euróövezeti csatlakozását jóváhagyó rendeletének hatályon kívül helyezése is (ebben az esetben kizárásról lenne inkább szó, nem kilépésről). Ezekben az esetekben a szuverén államadósság visszafizetése más megvilágításba helyeződne. A jelenlegi, mindkét szervezetben ( $E G M U, E U)$ meglévő tagságra tekintettel az államadósság elengedése Győrffy [2017, 28-29. o.] alapján három ok miatt nem lehetséges: 1 . az euróövezet kitettsége a GDP 3,3 százalékára tehetö, ami rendkívül magas, és valószínütlenné teszi az adósság elengedését, 2. egy esetleges görög adósságleírás könnyen dominóhatást válthatna ki; a befektetők elkezdenék találgatni, melyik ország jelent csődöt legközelebb; a kockázatosabb országok kiszorulnak a pénzpiacokról, és emiatt a csődöt illető várakozás önbeteljesítővé válik, 3. a görög adósság 82 százaléka külföldi joghatóság alatt áll, ami jelentősen megnehezíti az egyoldalú felmondást (lásd: korábban). Ezek ellenére a görög tartozások elengedését politikai és szakmai körökben egyre többen szorgalmazzák. ${ }^{8}$ A jelenlegi jogi helyzet alapján tehát a görög adósság hitelezők általi elengedésére nincs lehetőség, ehhez az Európai Unió fundamentumait jelentő szerződéseket kellene módosítani.

${ }^{8}$ A görög államadósság legalább egy részének elengedését javasolta az $I M F$, továbbá Thomas Piketty, Jeffrey Sachs, a fejlődésgazdaságtan egyik legelismertebb kutatójának számító Dani Rodrik, Simon Wren-Lewis, az Oxfordi Egyetem professzora, valamint Heiner Flassbeck, a német pénzügyminisztérium volt államtitkára (vs.hu, 2015). 


\section{Az intézményi változások hozzájárulása a görög államadósság-csökkentéshez, megvalósításuk jogi nehézségei}

Az eddig ismertetettek szerint a jövőben fennmarad a görög állam Európai Unióban példátlanul magas szuverén államadóssága, amit immár egy évtizedes folyamatos válságkezeléssel lehetett csak fenntartani. Ugyanakkor egyre gyakrabban jelennek meg politikai és szakmai állásfoglalások arra vonatkozóan, hogy Görögország adósságpályája hosszú távon a jelenlegi mértékben és struktúrában fenntarthatatlan. ${ }^{9}$ Ilyen válsághelyzetben Görögországban jelentős szerepet kapnak a privatizációs bevételek, amelyekkel érdemben lehetséges az államadósság mérséklése. Egyetlen más államadósság-finanszírozási plafonba került nemzetgazdaságban (lásd: PIIGS országok - Görögország, Írország, Portugália, Spanyolország, Olaszország) sincs olyan potenciál erre, mint éppen Görögországban. Ennek egyszerüen az a magyarázata, hogy a görögöknél az állami vagyon aránya a legmagasabb a többi országhoz képeset. Azonban az állami vagyonelemek magánkézbe adásának tervezete és eddigi gyakorlata rendkívül nagy társadalmi és politikai ${ }^{10}$ ellenállásba ütközik Görögországban. A programot 2011-ben kellett elkezdenie a görög kormánynak és 2015 végéig összesen 50 milliárd eurón ${ }^{11}$ értékben kellett volna magánkézbe adni állami vagyoneszközöket (IMF, 2011). A program azonban nem valósult meg, érdemben a múlt évben kapott újra lendületet, döntően azért, mert a harmadik, 86 milliárd eurós nemzetközi mentőcsomag nyújtásának ez volt az egyik feltétele. A program végrehajtásával szembeni társadalmi ellenállás nem mérséklődik, az állampolgárok többször tüntetésekkel adtak hangot a program végrehajtásával szembeni nemtetszésüknek. Különösen a közszolgáltatások magánosítása vált ki ellenérzéseket, de a kormány szerint a gazdaság működéséhez nélkülözhetetlenek a külföldi befektetések. A továbbiakban olyan, elsősorban jogi akadályokat mutatok be, amelyek

${ }^{9}$ Lásd a görög államadósság-pálya hosszú távú fenntarthatatlanságáról megjelent nyilatkozatokat (Social Europe, 2016), valamint az adósság mérsékléséről és ebben Németország felelősségéröl: Fortune.com [2015].

${ }^{10} \mathrm{Az}$ állami beavatkozás privatizáció általi csökkentése Görögországban is - mint minden más nemzetgazdaságban - megjeleníti a magánkézbe adás ellentmondásos hatásainak legfontosabb magyarázó tényezőjét, a privatizáció paradoxonát. E szerint: a privatizáció állami feladat, arról maguk a politikusok döntenek, sokkal inkább a maguk hasznára, mint a közérdekre tekintettel. A privatizáció célja lehet a politikusok beavatkozásának korlátozása a gazdaságba, a paradoxon abban nyilvánul meg, hogy erről az (ön-) korlátozásról éppen a politikusoknak kell döntést hozniuk (Yarrow-Jasinski, 1996).

${ }^{11}$ Az összeg a 2010-es GDP közel 22 százaléka, ehhez hasonló nagyságrendủ magánosítás a gazdaságtörténetben két alkalommal volt. Észtország 1992 és 1998 között a GDP 20,3 százalékával megegyező összegben, míg Magyarország 1991-1998 között a GDP 32 százalékának megfelelő értékben hajtott végre privatizációt (Török, 2012). 
érdemben hátráltatják a grandiózus privatizációs program véghezvitelét, amelyre azonban Görögországnak szüksége van azért, hogy müködésének finanszírozását fenntartsa. A külföldi működő tőkét és privatizációt leginkább akadályozó tényezők közé tartozik a bürokrácia magas foka, az adórendszer alacsony hatékonysága, a korrupció átlag feletti értéke és a jogrendszer kiszámíthatatlansága KaragiannisKondeas [2012] szerint.

A görög bürokrácialállamméret jellemzése

A görög bürokráciát elemezve kijelenthető, hogy az alapvetően az állam nagy méretével (éves GDP-hez mért kiadásainak magas arányával) jellemezhető (lásd az 5. ábrát). A bürokrácia szervezeti diszfunkciókhoz vezet. Így viszont a célok helyett az eszközök (föleg: a szabályok merev követése) válnak fontossá az állami szervezetekben. Ilyenkor a szervezet egyes jellemzői ellentmondásba kerülhetnek egymással. Az országban uralkodó bürokratikus állapotokról nagyon lehangoló ismertetések vannak, az állampolgárok és szervezetek, hazaiak és külföldiek naponta tapasztalhatják meg az állami és helyi közigazgatás lassúságát, tevékenységük alacsony hatékonyságát.

A GDP arányában mért államháztartási összkiadás 2007-ig mind az EU-28, mind az euróövezet tekintetében csökkent, majd 2007 és 2009 között gyorsan növekedve 2009-ben az EU-28-ban elérte a GDP 50,0 százalékát (az euróövezetben pedig a GDP 50,7 százalékát). Ezt követően 2009 és 2011 között a GDP arányában mért összkiadás mindkét terület tekintetében csökkent, 2012-ben nőtt, majd végül 2016ig ismét csökkent. Az EU-28 országaival ellentétben Görögország esetében szinte folyamatos az emelkedés, 2013-ban az Európai Unióban eddig példátlanul magas, 62,2 százalékon tetőzött a görög kormányzati kiadások GDP-hez mért aránya. Ettől kezdve - a megszorító intézkedések következtében - csökkenés tapasztalható, de a 2016. évi 49,7 százalékos mérték is jelentősen meghaladja az EU-28 átlagát. A görög kormány által bejelentett bürokráciacsökkentő lépésekre tehát elengedhetetlenül szükség van ahhoz, hogy a kormányzati kiadások tovább mérséklödjenek, végbemenjen tehát egy ambiciózus költségvetési kiigazítás annak érdekében, hogy a privatizációs program is végrehajtható legyen. 


\section{Görögország és az EU-tagok kormányzati kiadásainak alakulása a GDP százalékában}

(Százalékban, 2007-2016)

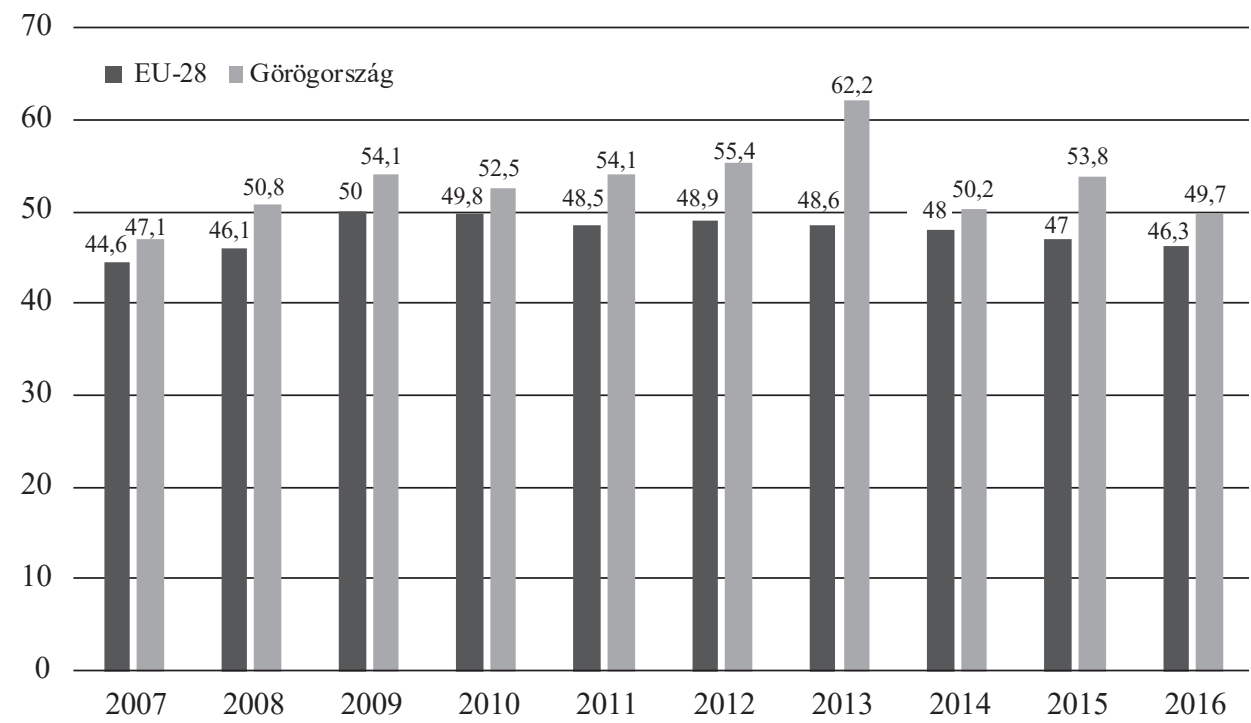

Forrás: Eurostat [2017d] alapján saját szerkesztés.

Az adórendszer müködésének alacsony hatékonysága

Az adórendszer működésének alacsony hatékonysága mindig is jellemző volt a görög társadalomra. Görögországban egy a napi.hu-n idézett felmérés szerint az igen alacsony szintủ adózási fegyelem miatt az állam évente 15-20 milliárd euró bevételtől esik el (napi.hu, 2012). Ugyanakkor a pénzügyi igazgatás sem eléggé hatékony, az adóbevételek 50 százalékát kitermelő 1000 legnagyobb adózót például szinte alig ellenőrzik, a behajtatlan adótartozások összértéke pedig 63 milliárd euró. Különösen kritikus a helyzet az általános forgalmi adó vonatkozásában, ennek beszedési hatékonysága Görögországban a legalacsonyabb az euróövezet országain belül. Az ország bennragadt egy alacsony hatékonyságú adórendszerben, ami rossz adórendszerrel, alacsony adómorállal, magas adócsalással és adóelkerüléssel jellemezhetö, ezért nagy hatékonyságveszteséggel és alacsonyabb növekedéssel leírható makrogazdasági állapotban van. Egy radikális adóreform jobb adómorállal, keve- 
sebb adócsalással és -elkerüléssel, gyorsabb növekedéssel járó jobb egyensúlyba vihetné át a görög gazdaságot. Ebben az összefüggésben különösen fontos, de nehezen előre jelezhető szerepet játszik az, hogy milyen csatornákon keresztül és hogyan hathat az adórendszer a polgárok adómoráljára. Szólnak érvek amellett, hogy a jól müködő állam és a jónak gondolt adórendszer javítja az adómorált. A német segítséggel bevezetésre váró adójogi reform jelentős változásokat fog hozni a görögöknél. Görögországban átalakítják 2019-ben az unió egyik legbőkezübb, a GDP 11 százalékát képviselő nyugdíjrendszerét, amelyben az ellátottak csaknem fele havi 660 eurót fog megkapni. A csökkentés az érintetteknek 7-30 százalékkal alacsonyabb járadékot vetít előre, a legalacsonyabb nyugdíjak azonban akár emelkedhetnek is. 2018-ban, de a 2019-es választási év jövedelmeire vetítve tágítják az unió egyik legszükebb adóbázisát, ugyanis a görögök fele nem fizet adót, az unióban pedig átlagosan 92 százalék fizet. Ennek következtében a jelenlegi 8600 eurós adómentes éves határt - családi helyzettől függően - legalább 7000, vagy akár 6000 euróra szállítják le. Mindez érinti a viszonylag alacsony nyugdíjakat is, így 1,3-1,4 millió ember kerül be az adózók körébe ( $v g . h u, 2017)$. Ez a legfontosabb lépés abba az irányba, hogy a görög adórendszer hatékonysága növekedjen, érdemben közeledjen az európai uniós átlaghoz.

A korrupció görögországi helyzete

Az ország korrupciós állapotáról mindent elárul az, hogy a görögök a méréshez használt index alapján 2016-ban a világ vizsgált 176 államából a 69. helyen végeztek, ezzel az egyik legkorruptabb országnak bizonyultak. Az európai uniós rangsorban is tovább rontotta helyzetét, mindössze Bulgáriát megelőzve utolsó elöttiként zárja a sort. A korrupció és a gazdasági teljesítmény összefüggéseiről számos nemzetközi kutatás, elméleti és empirikus tanulmány áll rendelkezésre. A korrupció a „rossz kormányzás” legfontosabb jele, amely többnyire együtt jár a jogállamiság megsértésével. A részrehajló, föleg az éppen aktuális elit hatalmát bebiztosítani hivatott állami intézmények ilyenkor nem üldözik, hanem eltürik, néha egyenesen ösztönzik a korrupciót, ez által az uralkodó hatalmi kör tagjainak még nagyobb hatalma lesz, az ország viszont szegényebbé válik. Az üzleti klíma rosszabbra fordulása a beruházások csökkenéséhez vezet, ami aláássa a fenntartható növekedést (Transparency International, 2017). Az előrelépés érdekében az Európai Bizottság munkacsoportja és a görög hatóságok átfogó nemzeti stratégia alapjául szolgáló korrupcióellenes ütemtervet fogadtak el. Ez alapján a görög hatóságok 2013 elején megállapodtak 
egy nemzeti korrupcióellenes stratégiáról, amely cselekvési tervet foglal magában. Ezzel hosszú ideje fennálló hiányosságot pótoltak, ami fontos előrelépést jelentett az ország korrupcióval kapcsolatos kihívásainak és a területtel kapcsolatos politikák összehangolása szükségességének kezelésében. A cselekvési terv végrehajtásának felügyeletére nemzeti korrupcióellenes koordinátort neveztek ki. A görögországi büntetőjogi jogszabályok kiterjednek a korrupcióval és a befolyással üzérkedéssel kapcsolatos büncselekmények minden olyan formájára, amelyek az Európa Tanács korrupcióellenes jogi eszközeinek hatálya alá tartoznak (EB, 2014, 2. o.).

\section{A jogrendszer kiszámithatatlansága}

A jogrendszer kiszámíthatatlanságának mérséklését alapvető elvárásként fogalmazták meg a hitelezők, teljesítése egyben a görög privatizációs program megvalósulásának is egyik feltétele. A jogrendszer egy adott államban vagy más politikai közösségben hatályos jogszabályoknak, illetve azok megalkotásának, értelmezésének és érvényesítésének rendszere. A görögök által vállalt szerkezeti reformok egyik területeként a jogrendszer megváltoztatását jelölték ki (Európai Számvevőszék, 2017, 17. o.). A görög kormány 77 törvény és adminisztratív szabály megváltoztatásáról döntött annak érdekében, hogy ezzel végre lehessen hajtani az állam és a közigazgatás modernizációját és fel lehessen pörgetni az állami vagyon eladását. A program egyik fő prioritása az állam és a közigazgatás modernizálása. Különösen fontos cél, hogy a közszektor hatékonyabb módon biztosítsa az alapvetö közjavakat és közszolgáltatásokat. A program része az igazságszolgáltatási rendszer hatékonyságának fokozása és a korrupció elleni küzdelem megerősítését szolgáló intézkedések. Emellett meg kell erősíteni a nemzeti intézmények - például az adóigazgatás és a statisztikai hatóság intézményi és müködési - függetlenségét is. A legjelentősebbek közé tartozik például annak a törvénynek a megváltoztatása, amely kötelezi a kormányt arra, hogy 51 százalékot tartson meg bármilyen közmücégben, és 20 százaléknál nagyobb részesedést semmilyen cég nem szerezhet ezekben a vállalatokban. Emellett olyan szabályozó hatóságok felállításába is belekezdenek, amelyek a közszolgáltató vállalatok eladását koordinálnák. A törvényi és egyéb jogszabályváltozások magukba foglalják és megcélozzák a forgalmi adózás egyszerüsítését, az adóalap kiszélesítését, a nyugdíjrendszer fenntarthatóvá tételét, a polgári peres eljárási törvény átalakítását, a nemzeti hivatalok függetlenségének szavatolását, az uniós bankszanálási és talpra állítási irányelv egyébként is kötelező, maradéktalan átvételét stb. (Európai Tanács, 2015). A privatizációs program sikeres véghezvite- 
lének talán az egyik legfontosabb feltétele a görög ingatlan-nyilvántartási rendszer megreformálása, az adatok pontosítása, az ingatlanok tulajdonjogának tisztázása. ${ }^{12}$

Az előzőekben bemutatott intézményi változások nem kizárólag a privatizációs program sikeres véghezvitelének, hanem a görög államadósság finanszírozhatóságának fenntartása érdekében tünnek elengedhetetlennek. Szükség lenne arra, hogy a társadalomban kialakuljanak a változások iránti társadalmi elköteleződések. Csaba [2013] szerint ennek hiányában ugyanis - minden társadalom vonatkozásában fennáll a már kialakított szabályok és intézmények kijátszásának veszélye.

\section{Privatizációs bevételek realizálásának várható körülményei}

A privatizációs program részletes feltételeit és szabályait az Európa Tanács és a Görög Köztársaság a Kiegészitö Megállapodás Emlékeztetőjében (az egyetértési nyilatkozat második kiegészítése, SM of U: Greece. 5 July 2017) fogalmazták meg és azt 2017. július 5-én írták alá (European Commission, 2017). A görög privatizációs programnak a 2011. évihez (lásd: Török, 2012) képest számottevően új elemei alig vannak, érdemben annak egyfajta dinamizálásáról van szó. Ez azért lehetséges, mert az előző magánosítási tervből az elmúlt hat évben alig valósult meg valami. Görögország hitelezői - élükön Németországgal - éppen ebből a felismerésből vetették fel újra az állami vagyoneszközök magántulajdonba adásának tervét. A program megvalósításához Görögország létrehozta a köztársaság Eszközfejlesztési Alapját, amely felügyeli az 50 milliárd euró értékủ állami vagyon privatizációját, az alap mintegy garanciaként szolgál az államadósság egy részének visszafizetésére, az mintegy a fedezetét adja annak, hogy az ebbe befolyó privatizációs bevételek egy része (negyede) közvetlenül az adósság törlesztésére fordítódik. Azért csak egy része, mivel az alapba befolyó bevételek felét a görög bankok feltőkésítésére kell fordítani. De hogyan lesz ebből privatizációs bevétel? A terv azzal számol, hogy a 25 milliárd eurós bevételből feltőkésítik az ország négy kereskedelmi bankját (amelyekben az állam jelenleg 55 százalékos részesedéssel rendelkezik) és ezután privatizálják azokat, majd az ebből befolyó bevételt fordítják az államadósság-törlesztésre. A fennmaradó egy negyedet (12,5 milliárd eurót) pedig állami beruházások finanszírozására

12 Kormányzati ellenőrök vizsgálták meg a Jón-tenger partvidékét annak érdekében, hogy felmérjék, milyen privatizációs potenciállal rendelkezik az állam tulajdonában lévő környék. Meglepetésükre 7000 olyan ingatlant, házat találtak, amelyek nem voltak bejegyezve az ingatlan-nyilvántartásba (New York Times, 2012). 
kell fordítani. A magánosítási program végrehajtásakor a görög politikai vezetésnek számolnia kell az állampolgárok ellenállásával, a társadalom egy része ugyanis az ország kiárusításaként viszonyul az állami vagyon privatizációjához. Szakértők is kritizálják a programot, főleg azért, mert nem látják a privatizációs program végrehajtása feltételeinek jelenbeli és jövőbeni meglétét (lásd az előzőekben leírtakat), azokét, amelyek görög részről a privatizációs program sikeres véghezvitelének garanciái lennének. A program vége (az optimistább, évente közel azonos bevétellel kalkuláló tervek szerint) 2022-re prognosztizálható.

\section{Egy realista forgatókönyv a görög szuverén államadósság jövőbeli alakulására}

Az Európai Tanács [2017, 8. o.] határozata szerint (amellyel megszüntette az országgal szembeni túlzottdeficit-eljárást) Görögország szuverén államadóssága 2016-ban tetőzött. A GDP-arányos államadósság a hátralékok felszámolásának folytatódásával 2017-ben várhatóan nagyjából változatlan marad, 2018-ban azonban a költségvetési többletnek és a kedvező konjunkturális körülményeknek betudhatóan a GDP 174,6 százalékára csökken. Ha az államadósság várható 2018. évi mértékéből indulok ki, ehhez figyelembe veszem a görög gazdaság 2022-ig várható gazdasági növekedésének értékeit a Statista [2018] alapján, továbbá a görög szuverén államadósság középtávon várható értékeinek alakulását, akkor elöre lehet jelezni ezen adósság várható értékét. Ennek bekövetkezésének intézményi alapja a jelen fejezetben a görög gazdaság és társadalom strukturális átalakulásával szemben megfogalmazott elvárások teljesülése. Ezek:

- a jelentős költségvetési kiigazítási program végrehajtása,

- a görög adórendszer hatékonyságának számottevő növekedése,

- a korrupció mérséklése, ami hozzájárulna a társadalmi-gazdasági klíma javulásához,

- a jogrendszer megváltoztatásával az állam és a közigazgatás modernizációja,

- a most dinamizált privatizációs program végrehajtási feltételeinek megteremtése. Mindezek eredőjeként - számításaim szerint - a szuverén görög államadósság 2022-re 265,9 milliárd euróra, az ekkorra számított 193,2 milliárd eurós GDP 137,6 százalékára mérséklődne. Önmagában tehát a privatizációs bevételek nem lesznek képesek a görög államadósságot olyan alacsony szintre vinni, hogy az kezelhető maradjon. A kalkulált több mint 40 százalékos adósságcsökkenés nem elhanyagolható, de nem elégséges. Ehhez az államadósság hitelezőinek csökkenteniük kellene a görög tör- 
lesztési terheket. A görög államkötvényeket törlesztési moratórium és a lejárati határidő meghosszabbítása nélkül nem lehet esedékességükkor visszafizetni. A megoldás - talán - az lehet, ha Görögországot legalább 2035-2040-ig mentesítik a törlesztési kötelezettség alól, és a hitelek határidejét pedig legkevesebb 2060-2070-ig prolongálják.

6. ábra

\section{Görögország középtávú GDP-jének és államadósságának alakulása 2016 és 2022 között}

(Milliárd euróban)

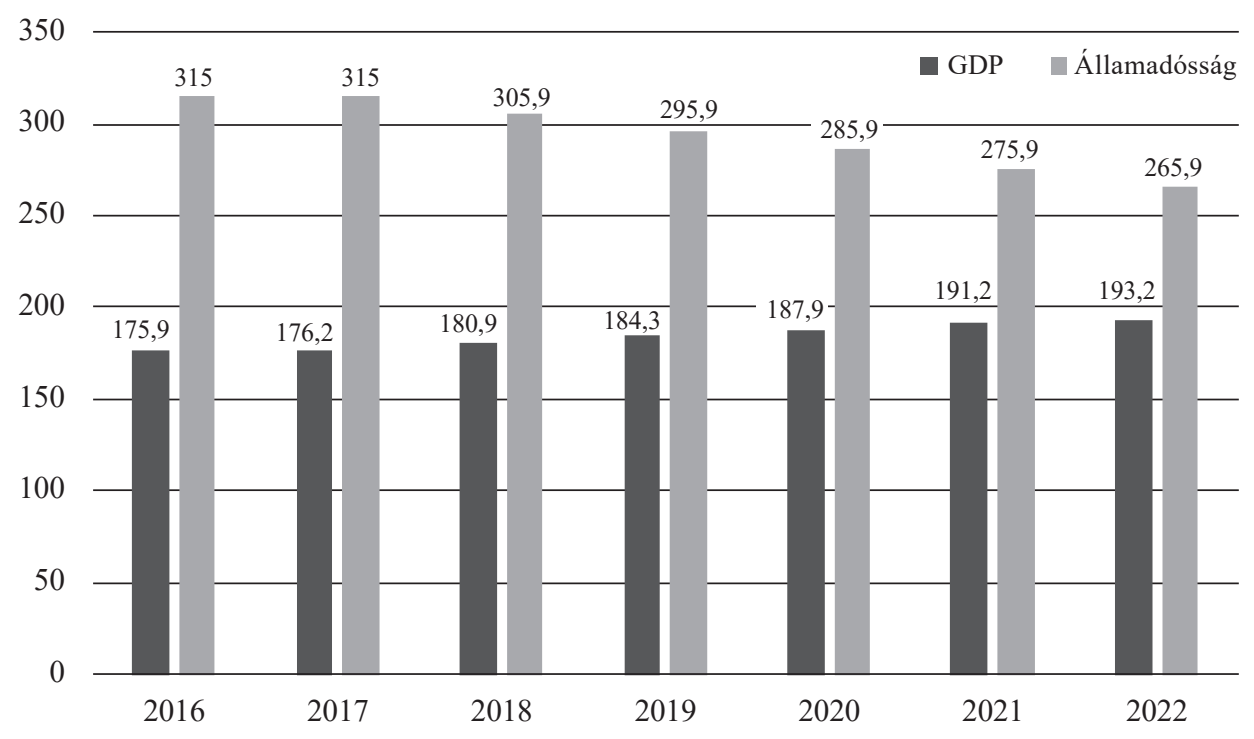

Forrás: GDP-növekedés: Statista [2018], államadósság: saját számítás.

A 6. ábrán az látható, hogy (a legoptimistább privatizációs forgatókönyv megvalósulása esetén) az egyszeri magánosítási állami bevételek átmenetileg megtörik ugyan az államadósság növekedését 2022-ig, sőt több mint 40 százalékkal mérséklik azt, ezáltal kezelhetőnek tüntetik fel annak mértékét. A 2022-es évet követően azonban a csökkenés dinamikája megtörne, mivel újabb privatizációs bevételekkel már nem lehet kalkulálni. Az IMF országjelentésében (IMF, 2017, 57. o.) kezelhetetlennek minősíti a görög szuverén államadósságot, amennyiben azt a hitelezőkkel történő megállapodásokban teljesen át nem strukturálják. Ennek hiányában 2060-ra a görög államadósságot az akkorra várható GDP 275 százalékára prognosztizálja. 


\section{Görögország rendezett vs. rendezetlen államcsődje}

Görögországban bekövetkezett az ún. rendezett államcsőd eseménye. Az államoknak nyújtott hitelekre gyakran gondolunk biztonságos befektetésként, lehetetlen vagy legalábbis valószerütlen kimenetelként kezelve az államcsőd lehetőségét. Pedig államcsődök azóta vannak, amióta szuverén államok hitelt vesznek fel, és még csak nem is ritka eseményekröl van szó (Vidovics-Dancs, 2014). Ez megtörtént 2012-ben Görögországban is. Ekkor a görög kormány megállapodásra jutott a magánbefektetőkkel az adósságelengedés azon általános feltételeiről, amelyek az összes magánszektorbeli kötvénytulajdonosra vonatkoznak. A megállapodásból kiderül, hogy a magánszektor képviselői a görög állampapírok névértékére vonatkozó követelésük 53,5 százalékát leírják (53,5 százalék körüli veszteséget, azaz értékcsökkenést szenvednek el), ez nagyobb veszteség a korábban tervezettnél, és a nettó jelenérték tekintetében több mint 70 százalékot jelent. A magánbefektetőkkel történt megállapodás az adósságcseréről (PSI) elengedhetetlen feltétele volt annak, hogy a második hitelprogram sikeres legyen. A kötvénycsere keretében 100 milliárd eurónyi régi kötvényért cserébe 31,5 milliárd eurónyi új (11-30 éves futamidejü) kötvényt és 15 milliárd rövid lejáratú EFSF-kötvényt ${ }^{13}$ kaptak a magánbefektetők (ez összesen 46,5 milliárd euró, ebből fakad az 53,5 százalékos hair cut). A magánbefektetők nagy arányban vettek részt az adósságcserében, ami jelentősen hozzájárult a görög államadósság fenntarthatóságához. Az új kötvények kamata 2014-ig csupán kétszázalékos lesz, majd 2020-ig 3, csak azt követően emelkedik 4,3 százalékra. Bekövetkezett tehát az államcsőd Görögországban, mivel így szokás nevezni azt a helyzetet, ha egy szuverén állam valamely hiteltípusú kötelezettségével kapcsolatos fizetési kötelezettségének nem vagy nem az eredeti feltételekkel tesz eleget, és a hitelezőnek ebből kára származik. Releváns volt ebben a folyamatban, annak végeredményeként született megállapodásban, hogy a hitelezök önként mondtak le követelésük egy jelentős részéről, ettől tekinthetjük rendezettnek a görög államcsődöt. Joggal merül fel a kérdés, hogy a hitelezők miért fogadtak el rájuk nézve ennyire súlyos veszteséggel járó (mínusz 53,5 százalékos) feltételeket. Ennek magyarázata az, hogy nem volt más választásuk, ugyanis az államnak mint szuverén adósnak nyújtott hitelek esetében nincsenek jól definiált jogi következményei egy esetleges törlesztési mulasztásnak vagy elmaradásnak, ezért a bíróság általi kikényszerítésnek vagy vagyonelkobzásnak sincsenek meg sem a jogi, sem az intézményi feltételei. Tulajdonképpen az

\footnotetext{
13 EFSF-kötvény: az euróövezeti ideiglenes mentőalap kötvénye.
} 
egyetlen alternatív megoldás lehet az adós országok eszközeinek önkényes lefoglalása. A görögök másik választási lehetősége lett volna egy úgynevezett rendezetlen államcsődbe való menekülés.

\section{Záró gondolatok}

1. Az előző pontban egy várható görög államadósság-pályát prognosztizáltam 2020-ra az ismert görög körülményekre, a már megtett és még tervezett intézményi változásokra, statisztikai előrejelzésekre és a privatizációs tervekre alapozva. $\mathrm{E}$ helyzet bekövetkezéséhez azonban semmiképp nem szabad figyelmen kívül hagyni egy releváns körülményt, amelyre az előzőekben már utaltam. Az eddig végrehajtott és még végrehajtani tervezett intézményi változásokhoz el kellene nyerni a görög társadalom bizalmát és támogatását. Ennek megteremtése a politikai hatalom gyakorlóinak feladata és felelőssége. Az intézményi reformok és változások mindig érintik a társadalmi jövedelmek el- és újraosztását, amire a társadalom különböző rétegei eltérő mértékben és hevességgel reagálnak, megvalósításukhoz tehát nélkülözhetetlen a már említett társadalmi bizalom és támogatás megszerzése. Ennek elnyerése talán még nehezebb feladat a görög politikai irányítók számára, mint az államadósság hitelezőivel történő megállapodások megkötése, esetenként azok jövőbeli módosítása. A reformokkal és változásokkal szembeni társadalmi konszenzus hiánya ugyanis - nem kizárólag a görögök vonatkozásában - megnöveli egy társadalmi-gazdasági összeomlás valószínűségét.

2. A görög államadósság közeljövőben várható finanszírozási keretében megteendő lépések - köztük az előbbiekben bemutatott várható pozitív intézményi változások, a finanszírozók elöre jelzett további erőfeszítései, a görög állami vagyon magánosításának dinamizálása stb. - együtt is csak részeredményekkel járhatnak. Az elvégzett változtatások és az előzőkben bemutatott inkább optimista szcenárió eredményeként mutatkozó jelentős, 40 százalékot meghaladó államadósság-mérséklődés után is olyan magas arányú maradna a görög szuverén bruttó államadósság, hogy annak hosszú távú finanszírozhatósága továbbra is rendkívül bizonytalan marad. Megítélésem szerint elérkezett az ideje annak, hogy a görög példa kapcsán (amely alapvetően a hitelek visszafizethetetlenségének irányába mutat) a jogirodalom elkezdjen foglalkozni egy önálló állami csődjog kidolgozásával, amelynek következtében elkerülhetővé válna, hogy tömeges magánjogi perek induljanak meg egy állam ellen annak fizetésképtelenné válása esetén. Az önálló állami csődjoggal ugyanis a befektetők szuverén államokkal kötött hitelszerződéseinek jogi kikényszeríthetősé- 
ge biztosítottá válna. Görögország esetében pedig az állami csőd bekövetkezésének gondolatával célszerü barátkozni.

\section{Irodalomjegyzék}

Baksay Gergely - Palotai Dániel [2017]: Válságkezelés és gazdasági reformok Magyarországon, 2010 2016. Közgazdasági Szemle, LXIV. évf., július-augusztus, 698-722. o.

Concorde [2018]: A pénzügyi elnyomás. Letölthető: http://premiumbanking.con.hu/penzugyielnyomas/, letöltve: 2018-01-12

Csaba László [2013]: Válságkezelés Európában: új gazdaságfilozófia felé? (Towards a New Philosophy of Crisis Management in Europe?) Köz-gazdaság, Vol. 8., No. 2., 47-61. o.

EB [2010]: The Economic Adjustment Program for Greece. Occasional Papers, No. 61. Európai Bizottság, Gazdasági és Pénzügyi Főigazgatóság, Brüsszel.

EB [2014]: Melléklet a következöhöz: Az Európai Unió antikorrupciós jelentése. Brüsszel.

Európai Tanács [2015]: Görögország: a harmadik gazdasági kiigazítási program. Brüsszel.

Európai Tanács [2017]: A Tanács Határozata a Görögországban fennálló túlzott hiányról szóló 2009/415/EK határozat hatályon kívül helyezéséröl. Brüsszel.

European Commission [2017]: Financial assistance to Greece, Information on the stability support programme, its implemention and reviews in Greece. Letölthetö: https://ec.europa.eu/info/ business-economy-euro/economic-and-fiscal-policy-coordination/eu-financial-assistance/, letöltve: 2018-01-14

Európai Számvevőszék [2017]: Az Európai Bizottság beavatkozása a görög pénzügyi válságba. Letölthető: www.eca.europa.eu/Lists/ECADocuments/SR17_17/SR_GREECE_HU.pdf, letöltve: 2018-01-13

Eurostat [2017a]: General government deficit. Letölthető: http://ec.europa.eu/eurostat/tgm/table.do?tab $=$ table \&plugin $=1 \&$ language $=$ en\&pcode $=$ teina20 letöltve: $2018-01-12$,

Eurostat [2017b]: General government gross debt. Letölthető: http://ec.europa.eu/eurostat/tgm/table.do $?$ tab $=$ table \&init $=1 \&$ language $=$ en \&pcode $=$ tsdde $410 \&$ plugin $=1$, letöltve: $2018-01-12$

Eurostat [2017c]: File: HICP all-items, annual average inflation rates, 2006-2016 (\%) YB17.png. Letölthető: $\quad$ http://ec.europa.eu/eurostat/statistics-explained/index.php?title=File:HICP_allitems,_annual_average_inflation_rates,_2006-2016_(\%25)_YB17.png\&oldid=345530, letöltve: 2018-02-28

Eurostat [2017d]: Government revenue, expenditure and main aggregates. Letölthetö: http://appsso. eurostat.ec.europa.eu/nui/print.do\#, letöltve: 2018-01-13

Fortune.com [2015]: Piketty: Germany's stance on Greece is a grave danger to Europe. Letölthető: http://fortune.com/2015/07/06/germany-greece-piketty-austerity/, letöltve: 2018-01-13

Gálik Zoltán [2012]: Görögország távozásának lehetséges forgatókönyvei az euróövezetből. Letölthető: http://www.grotius.hu/doc/pub/XZUWTT/gorogorszag\%20kilepese\%20az\%20euro\%20 ovezetbol.pdf, letöltve: 2018-01-12

Górniewicz, G. [2016]: The problem of general government debt in PIIGS group countries with the special attention paid to Greece. Central European Review of Economics \& Finance, Vol. 13., No. 3., 29-40. o.

Gray, J. [2013]: International Economic Organization and Sovereign Risk in Emerging Markets. Cambridge University Press.

Guzman, M. [2016]: Definitional issues in the IMF debt sustainability analysis framework - a proposal. CIGI Policy Brief. No. 77. Letölthető: https://www.cigionline.org/sites/default/files/pb_no.77_web. pdf, letöltve: 2018-02-12 
Győrffy Dóra [2014]: Válság és válságkezelés Görögországban. A puha költségvetési korlát szerepe a gazdasági összeomlásban. Közgazdasági Szemle, LXI. évf., 1. sz., 27-52. o.

Győrffy Dóra [2017]: Görögország a monetáris unióban: a kilépés hiábavalósága. Magyar Tudomány. Letölthető: http://www.matud.iif.hu/2017/01/04.htm, letöltve: 2018-01-10

Hallerberg, M. [2004]: Domestic Budgets in a United Europe: Fiscal Governance from the End of Bretton Woods to EMU. Cornell University Press, Ithaca-London.

IMF [2011]: Country Report (Greece), No. 11/175. Washington, D.C., 2011. július.

IMF [2017]: Country Report (Greece), No. 17/40. Washington, D.C., 2017. február.

Karagiannis, N. - Kondeas, A. [2012]: The Greek Financial Crisis and a Developmental Path to Recovery: Lessons and Options. Real-World Economics Review, 60. 54-73. o. Letölthetö: http:// www.paecon.net/PAEReview/issue60/KaragiannisKondeas60.pdf, letöltve: 2018-01-13

Krugman, Paul [2012]: Elég legyen a válságból! Most! Akadémiai Kiadó, Budapest.

KSH [2017]: Az államháztartás adóssága (1995-2016). Letölthető: https://www.ksh.hu/docs/hun/ eurostat tablak/tabl/tsdde410.html, letöltve: 2018-01-12

Losoncz Miklós - Farkas Péter [2011]: Nemzetközi pénzpiacok. Szent István Egyetem, Győr.

Monokroussos, P. - Stamatiou, T. G. - Gogos, S. [2015]: GRexit and Why It Will Not Happen. Eurobank Global Research: Greece MacroMonitor. Június 8. Letölthető: http://papers.ssrn.com/ sol3/papers. cfm?abstract_id $=2616278$

napi.hu [2012]: Keletnémet minta alapján szervezik át a görög pénzügyi igazgatást. Letölthető: www. napi.hu/nemzetkozi_gazdasag/nemet_gyamsag_ala_kerul_a_gorog_adohivatal_is.511771.html, letöltve: 2018-02-12

New York Times [2012]: Privatizing Greece, Slowly but Not Surely. Letölthető: https://www.google. hu/search? q=privatization+of+Greece+is+less+than+but+not+certain, letöltés ideje: 2018-01-14

Oblath Gábor [1999]: A maastrichti szerződés fiskális kritériumai és a hazai államháztartási helyzet értelmezése. Közgazdasági Szemle, XLVI. évf., 10. sz., 851-872. o.

Reinhart, C. - Rogoff, K. [2010]: Growth in a Time of Debt. American Economic Review: Papers \& Proceedings, Vol. 100., május, 573-578. o.

Social Europe [2016]: Poul Thomsen, Greece and IMF cynicism. Letölthető: https://www.socialeurope. eu/tag/imf, letöltve: 2018-01-13

Statista [2018]: Greece: Real gross domestic product (GDP) growth rate from 2012 to 2022. Letölthetö: https://www.statista.com/statistics/263605/gross-domestic-product-gdp-growth-rate-in-greece/, letöltve: 2018-01-16

The Economist [2013]: The 90\% question. Letölthetö: https:/www.economist.com/news/finance-andeconomics/21576362-seminal-analysis -relationship-between-debt-and-growth, letöltve: 2018-02-12

Török László [2012]: Államadósság és privatizáció. Vezetéstudomány, XLIII. évf., 7-8. sz., 117-125. o.,

Tradingeconomics [2018]: Greece Government Bond 10 Y. Letölthetö: https://tradingeconomics.com/ greece/government-bond-yield, letöltve: 2018-01-12

Transparency International [2017]: Corruption Perceptions Index 2016. Letölthető: https://www. transparency.org/news/feature/corruption_perceptions_index_2016, letöltve: 2018-01-13

$v g . h u$ [2017]: Alakul a görög alku: kis élénkítésnek nagy megszorítás lesz az ára. Letölthető: https://www.vg.hu/gazdasag/alakul-a-gorog-alku-kis-elenkitesnek-nagy-megszoritas-lesz-azara-486691/, letöltve: 2018-01-13

Vidovics-Dancs Ágnes [2014]: Az államcsőd költségei régen és ma. Közgazdasági Szemle, LXI. évf., 3. sz., 262-278. o.

Yarrow, G. - Jasinski, P. [1996]: Privatization, Critical Perspective on the World Economy. London and N.Y., Routledge, 1-47. o. 